\title{
EFFECT OF FIBRIN DEGRADATION PRODUCTS ON FIBRINOLYTIC PROCESS
}

\author{
T. A. YATSENKO, V. M. RYBACHUK, O. I. YUSOVA, \\ S. M. KHARCHENKO, T. V. GRINENKO
}

Palladin Institute of Biochemistry, National Academy of Sciences of Ukraine, Kyiv; e-mail:topolius@yandex.ua

\begin{abstract}
Fibrin clot lysis by plasminogen/plasmin system results in fibrin degradation products formation with subsequent release into bloodstream. The fragments contain specific binding sites for fibrinolytic system components and can interact with them. In this study, we investigated the way in which fibrin fragments effect fibrinolytic process. We have shown that high molecular weight products of fibrin degradation and fibrin fragments of DDE-complex and DD, but not end product $E_{3}$, stimulate plasmin formation. Additionally, components of DDE-complex mixture of fragments $E_{1}$ and $E_{2}$ have potentiation ability. The intermediate fibrin fragments hmFDPs and DDE attenuate clot lysis by plasmin and hmFDPs protect plasmin from $\alpha_{2}$-antiplasmin inhibition but under further fragmentation to endpoint fibrin fragments loose this ability. The plasma inhibitors reduce fibrinolytic system activity generated by the degradation products. Thus, fibrin fragments formed during the clot lysis can bind and move out fibrinolytic system components from clot volume and in this way result in clot resistance to hydrolysis.
\end{abstract}

Key words: fibrin degradation products, plasminogen, $t$-PA, activation, potentiation effect, plasmin inhibition.

$\mathrm{F}$ ibrin degradation products (FDPs) formation with subsequent release into bloodstream is a result of fibrinolytic system action. The main fibrinolytic enzyme plasmin is generated from inert precursor plasminogen by either tissuetype plasminogen activator (t-PA) or urokinase-type plasminogen activator [1]. According to molecular mechanism of fibrinolysis, plasminogen and its tissue-type activator from plasma bind to fibrin, and plasminogen activator converts proenzyme into plasmin. Fibrin formed during clotting process, as fibrinogen polymerization result is a high-avid substrate and at the same time a stimulator for plasmin. Plasminogen/t-PA binding sites in D-regions subsequently $A \alpha 148-160$ and $\gamma$ 312-324 are hidden in fibrinogen molecule and exposed under polymerization and fibrin clot formation [2]. The conversion provides increase of plasminogen and its activator local concentration, change of their conformation and orientation, resulted in fast proenzyme activation and fibrin cleavage by newly formed plasmin.

First step of degradation of individual fibrin(ogen) molecule by plasmin is $\alpha \mathrm{C}$-domains removal and $\mathrm{X}$-fragment formation. Than plasmin cleaves one of the coiled-coil connector and re- moves one of D-domains forming Y-fragment. The last stage is core fragments $\mathrm{D}$ and $\mathrm{E}$ formation. The lysis of polymeric fibrin cross-linked by FXIIIa leads to formation of intermediate high-molecular weight products that are the protofibril parts, for example DX $\mathrm{D}, \mathrm{DXY}, \mathrm{YY}, \mathrm{DY}$. In vivo these molecules can form supramolecular complexes due to the noncovalent DDE-interaction [3] and contain different number of DDE-blocks. In this work the complex of soluble high molecular weight fibrin degradation products are called hmFDPs. During further degradation, these products are hydrolyzed to DDE-complexes (two covalently bound D-domains noncovalently associated with fragment $E_{1}$ or $E_{2}$ ) and then to core fragments DD and $E_{3}$. Fibrin degradation products get in wide range of biological processes and affect all stages of hemostasis [4]. Soluble products of fibrin degradation stimulate t-PA-induced fibrinogen proteolysis in blood plasma [5]. FDPs activate inflammatory and/or structural cells and regulate smooth muscle cell migration [6]. Like fibrin, DDE-complex can bind plasminogen and its activator [7]. DD-fragment, a biomarker for hyperfibrinolytic disorders such as disseminated intravascular coagulation (DIC), attenuates the fibrin 
polymerization, influences inflammatory process by interaction with monocytes and stimulate increased cytokine production in peripheral blood monocytes and leukemia cell lines [8]. Fibrin fragment E induces leukocyte cytokine expression and migration by binding vascular endothelial-cadherin and monocyte and neutrophil migration [9]. At the same time the effect of fibrin degradation products accumulated in clot surrounding during its lysis on fibrinolytic system activity is still unclear.

This study investigates the action of products of fibrin degradation by plasmin on the different stages of fibrinolytic process, such as plasminogen activation by t-PA and fibrin hydrolysis by plasmin.

\section{Materials and Methods}

Fibrinogen was purified from human plasma by fractionation with sodium sulfate [10].

Plasminogen with an amino-terminal glutamic acid residue (Glu-plasminogen) was prepared from citrate donor plasma using the Lysine-sepharose 4B affinity chromatography [11].

Plasmin was prepared by activation of Gluplasminogen with urokinase, immobilized to Sepharose 4B [11].

Recombinant single-chain t-PA was a Boehringer Ingelheim product known as the trade name "Actylise".

desAB-fibrin was obtained by dissolving of thrombin fibrin clot formed in the presence of $50 \mathrm{mM} \varepsilon$-aminocaproic acid ( $\varepsilon$-ACA) and parahy- droxy mercury benzoate $(0.35 \mathrm{mg} / \mathrm{ml})$ in $20 \mathrm{mM}$ acetic acid as described elsewhere [12].

Cross-linked fibrin was obtained by thrombininduced fibrinogen polymerization (2 NIH of thrombin per $1 \mathrm{mg}$ of fibrinogen) in the presence of calcium ions $(0.25 \mathrm{M})$ at $25^{\circ} \mathrm{C}$ during $4 \mathrm{~h}$. Concentration of fibrinogen was $16 \mathrm{mg} / \mathrm{ml}$.

Fibrin degradation products were prepared from plasmin digest of human cross-linked fibrin. Digestion was performed in $0.05 \mathrm{M}$ TBS with $0.15 \mathrm{M}$ $\mathrm{NaCl}$ ( $\mathrm{pH}$ 7.4), concentration of plasmin was $0.2 \mathrm{CU} /$ $\mathrm{ml}$. Endpoint degradation products E- and DD-fragments were obtained by 16 -hour plasmic digestion at $25^{\circ} \mathrm{C}$ as described elsewhere [13]. Reaction was inhibited by $1000 \mathrm{KIU}$ aprotinin (Merckle $\mathrm{GmbH}$ ) per $1 \mathrm{ml}$ of reactive solution with $\varepsilon$-aminocaproic acid ( $\varepsilon$-ACA) and EDTA in final concentrations $20 \mathrm{mM}$. Dialysis of digest was performed in $10 \mathrm{mM}$ PBS pH 6.0 with $10 \mathrm{KIU} / \mathrm{ml}$ aprotinin, $20 \mathrm{mM}$ c-ACA and $20 \mathrm{mM}$ EDTA at $4{ }^{\circ} \mathrm{C}$. Fragments E and DD were purified by ion-exchange chromatography on CMSephadex G-50 (Fig. 1). Fragment DD was eluted by $20 \mathrm{mM}$ PBS with $300 \mathrm{mM} \mathrm{NaCl}$ (pH 7,6). Both fragments were then dialyzed in $0.05 \mathrm{M}$ TBS with $0.15 \mathrm{M} \mathrm{NaCl}(\mathrm{pH} 7.4)$ at $4{ }^{\circ} \mathrm{C}$.

Early plasmic degradation products DDE-complex and high molecular weight fibrin fragments hmFDPs were isolated by modified method [14] using Sephacryl S300 (Fig. 2). Cross-linked fibrin gel was hydrolysed by plasmin during $72 \mathrm{~h}$ at $25^{\circ} \mathrm{C}$ by $0.01 \mathrm{CU}$ plasmin per $1 \mathrm{ml}$ of reaction mixture. Fibrin
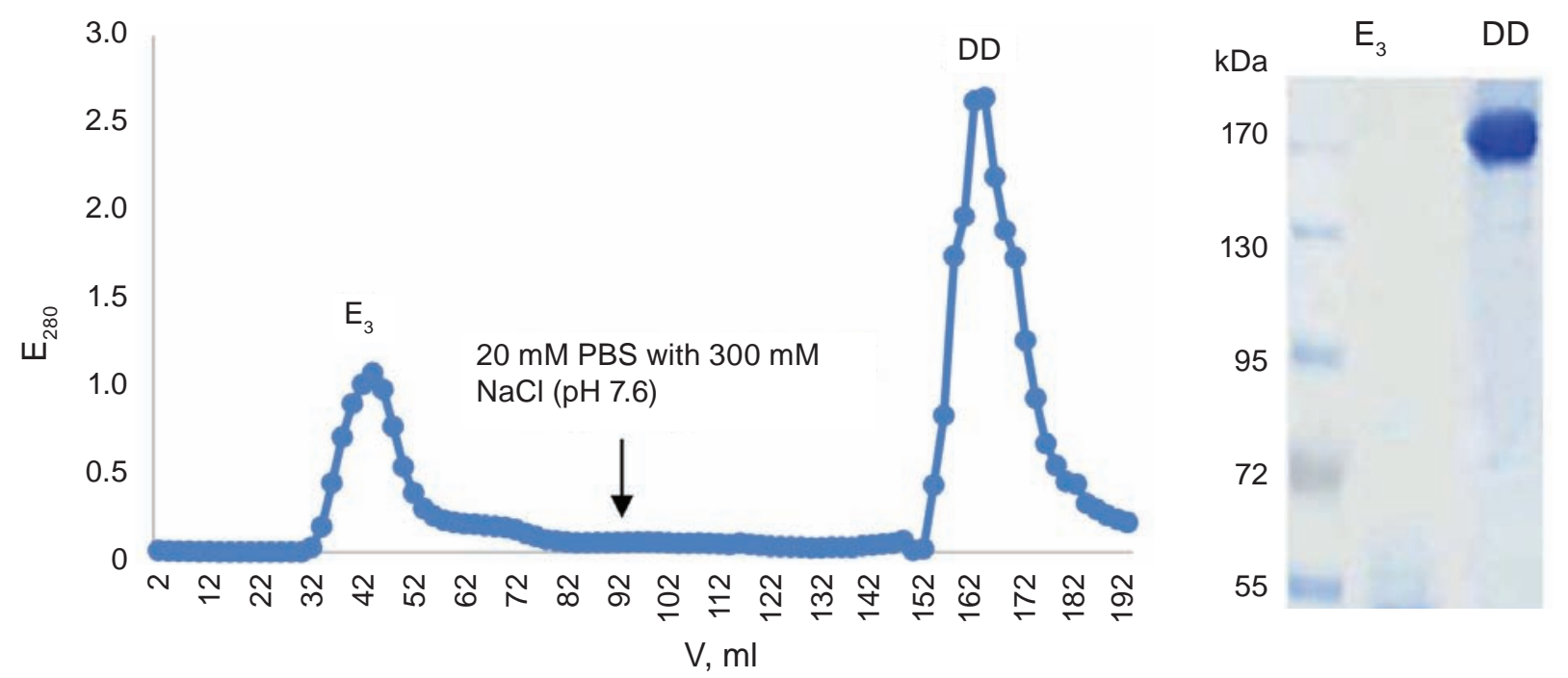

Fig. 1. Core fibrin degradation products separation using ion-exchange chromatography by CMSephadex-G-50. Elution graph of $E_{3}$ and DD fragments and electrophoretic analysis of proteins purity in $10 \%$ $S D S-P A G E$ 
concentration was $10 \mathrm{mg} / \mathrm{ml}$. Hydrolysis products were purified in the presence of plasmin inhibitor aprotinin $(25 \mathrm{KIU} / \mathrm{ml})$ and then concentrated and dialyzed using 50K Amicon filtration system (Millipore).

Fragments $E_{1} E_{2}$ mixture was obtained by noncovalent complex DDE dissociation in presence of 3.0 $\mathrm{M}$ urea at $37{ }^{\circ} \mathrm{C}$ during 1 hour. Dissociation products were isolated by size-exclusion chromatography using Sephacryl S300 (Fig. 3). Product of DDE dissociation fragment DD was not used in experiments because of its denaturation under dissociation conditions.

Protein concentrations were calculated by measurement of the absorbance at 280 and $320 \mathrm{~nm}$ using $\mathrm{E}_{1 \%}{ }^{280}$ and molecular weights, respectively: Glu-plasminogen, 17.0 and 92 000; plasmin, 17.0 and 84 000; tPA, 20.0 and 59 000; fibrinogen, 15.5 and 340 000; desAB fibrin, 14,48 and 300 000; hmFDPs, 16.0 and 500 000; fragment DDE-complex, 16.0 and 250000 ; fragment DD, 20.0 and 180000 ; fragments $\mathrm{E}_{1} \mathrm{E}_{2}$ mixture, 10.0 and 53000 ; fragment $\mathrm{E}_{3} 10.0$ and $45000[14,15]$.

Effect of fibrin fragments on the t-PA-catalyzed conversion of plasminogen into plasmin was evaluated by determination of the amidolytic activity of the newly formed plasmin with chromogenic substrate S-2251 (H-D-valyl-L-leucyl-L-lysine-p-nitroanilide).
The assay system contained $0.22 \mu \mathrm{M}$ Glu-plasminogen, $0.09 \mathrm{nM} \mathrm{t}-\mathrm{PA}, 0.3 \mathrm{mM} \mathrm{S}_{2251}$, and $0.625 \mu \mathrm{M}$ desAB-fibrin and/or $0.22 \mu \mathrm{M}$ fibrin fragments in $0.05 \mathrm{M}$ TBS with $0.15 \mathrm{M} \mathrm{NaCl}$ (pH 7.4) containing $0.05 \%$ Tween 80 . The assay was performed in microtiter 96 -well plate at $37^{\circ} \mathrm{C}$. The amidolytic activity was determined by measurement of the absorbance at $405 \mathrm{~nm}$ using Titertek Multiscan MC 96-well plate reader.

For the estimation of FDPs effect on fibrin clot lysis by t-PA-activated plasminogen, the turbidimetric method was applied as described in [14]. The final concentration of desAB-fibrin was $0.6 \mu \mathrm{M}$, Glu-plasminogen $-0.02 \mu \mathrm{M}$, t-PA $-0.001 \mu \mathrm{M}$. Fibrin fragments were added in 0.1-0.4 molar ratio to desAB-fibrin. The rate of fibrin clot lysis was calculated as $\mathrm{V}=1 / \mathrm{t}_{50 \%}$. Time of $50 \%$ lysis $\left(\mathrm{t}_{50 \%}\right)$ was measured as the time period from the initiation step of the clot formation till the step characterized by $50 \%$ fall in absorbance from maximum.

To test plasmin inhibition by plasma inhibitors turbidimetric analysis of clot lysis was performed after subsequent preincubation of fibrin fragment with plasmin during $3 \mathrm{~min}$ and addition to the reaction mixture $1-20 \mu 1$ of plasminogen-depleted blood plasma as source of plasmin inhibitor $\alpha_{2}$-antiplasmin and desAB fibrin. The final concentration of desABfibrin was $0.6 \mu \mathrm{M}$, plasmin $-0.02 \mu \mathrm{M}$. The max con-
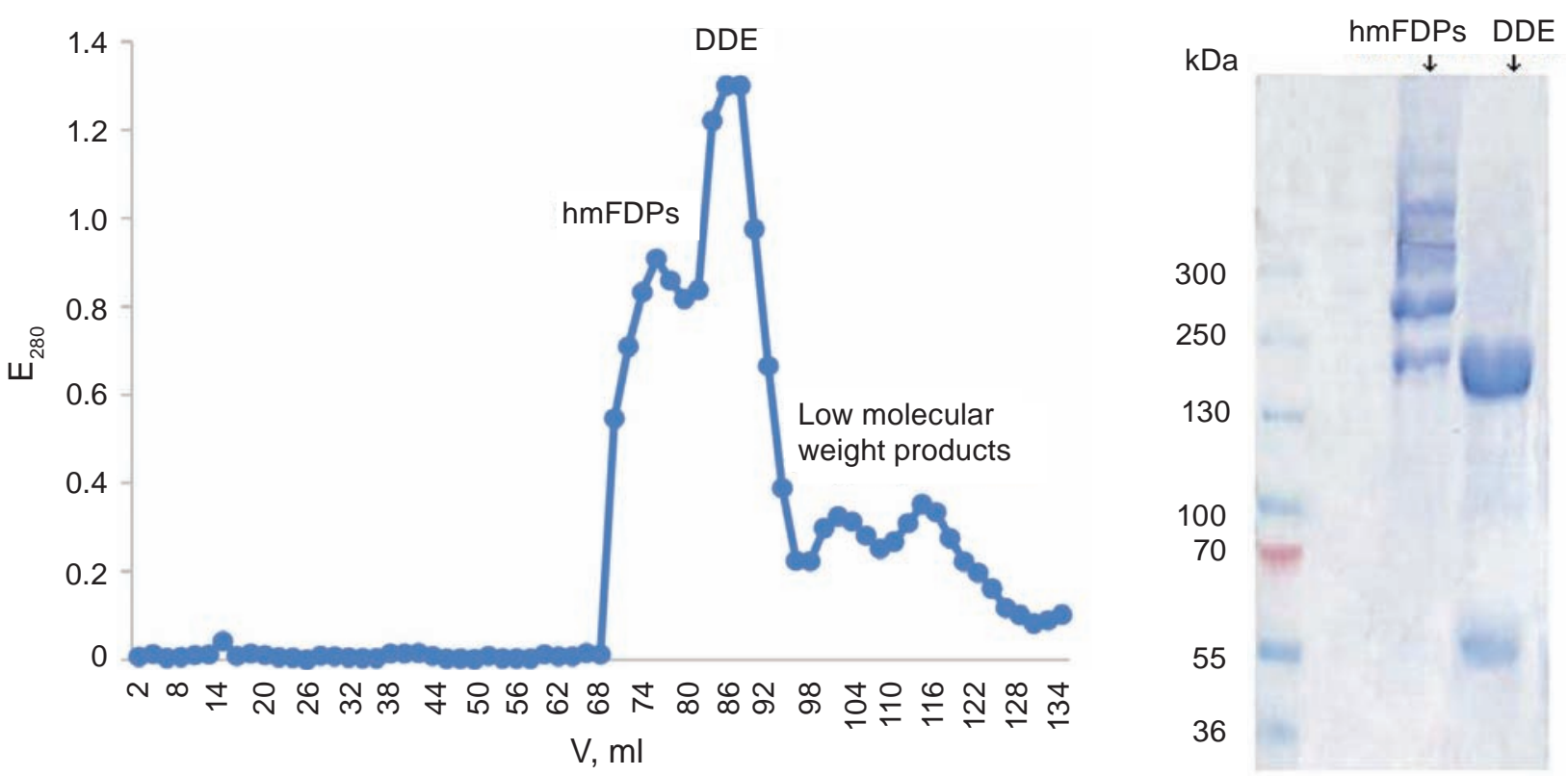

Fig. 2. Early fibrin degradation products purification by size-exclusion chromatography using Sephacryl S300. Elution of hmFDPs and DDE-complex. Fractions No. 70-76 (hmFDPs) and 84-92 (DDE) were concentrated and analyzed by $8 \%$ SDS-PAGE 

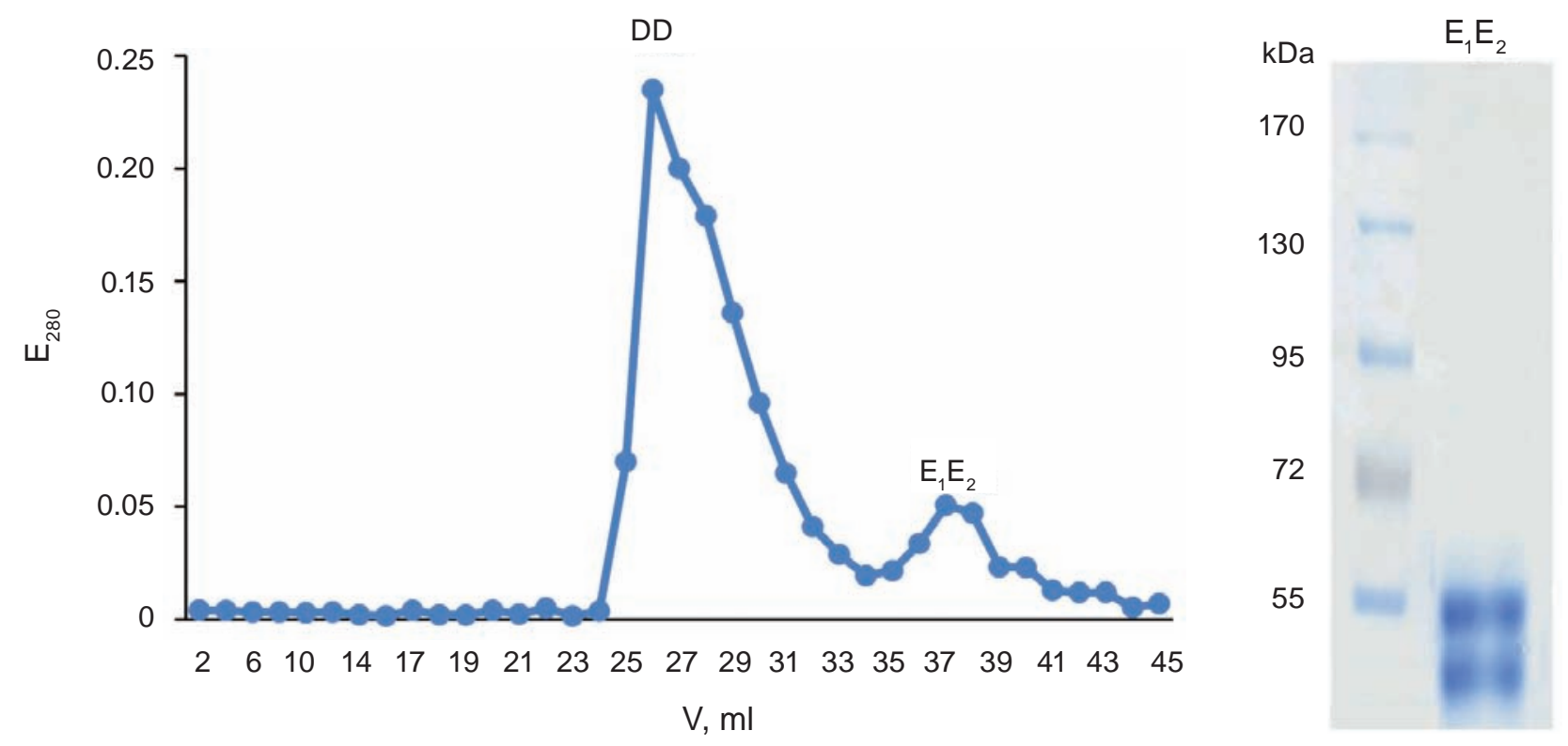

Fig. 3. Purification of noncovalent complex DDE dissociation products by size-exclusion chromatography using Sephacryl S300. Fragments $E_{1} E_{2}$ and DD elution peaks and electrophoretic analysis of $E_{1} E_{2}$ purity in $12 \%$ SDS-PAGE

centration of $\alpha 2$-antiplasmin equal to $20 \mu 1$ of blood plasma was $0.02-0.03 \mu \mathrm{M}$.

\section{Results and Discussion}

Potentiation of t-PA-mediated Glu-plasminogen activation by FDPs. All products of fibrin degradation by plasmin, apart from core fragment
$\mathrm{E}_{3}$, have potentiating effect on plasminogen activation by t-PA (Fig. 4, A). The rate of activation on intermediate fibrin degradation products hmFDPs and DDE-complex is similar to the rate on desAB fibrin, whereas endpoint degradation products decrease (DD) or completely lose $\left(\mathrm{E}_{3}\right)$ the potentiating ability. The mixture of DDE-complex components
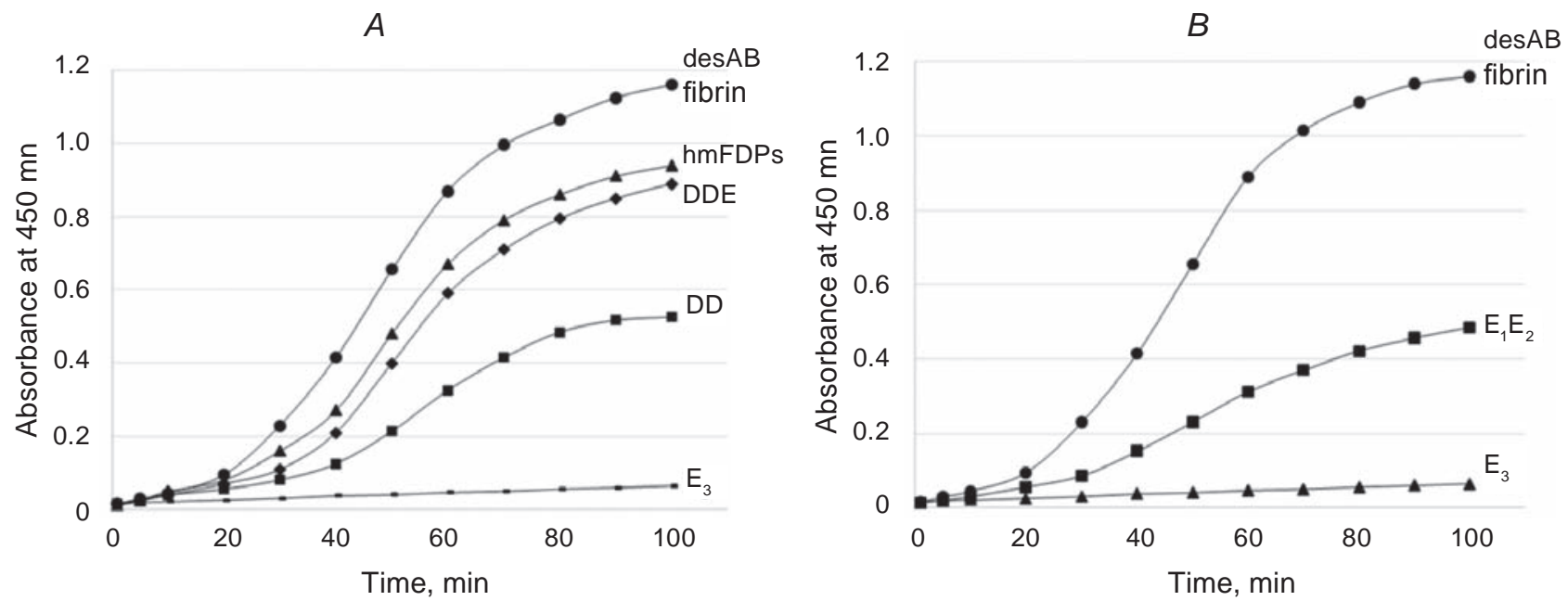

Fig. 4. Potentiating effect of fibrin fragments hmFDPs, $D D E, D D$ and $E_{3}(A)$ and DDE dissociation product fragment $E_{1} E_{2}$ comparing with endpoint degradation product of fibrin fragment $E_{3}(B)$ on Glu-plasminogen activation by tissue-type activator. Activation curves were fitted using absorbance changes during chromogenic substrate conversion by plasmin formed upon activation. Reaction mixture contained fibrin fragment or desAB-fibrin, Glu-plasminogen, $t$-PA and $S_{225}$. Kinetic curve of desAB fibrin is shown as a control. Kinetic curves were typical of three experiment series 
fragments $\mathrm{E}_{1} \mathrm{E}_{2}$ can interact with proenzyme and its activator and potentiate activation process, but after conversion to the fragment $\mathrm{E}_{3}$ loses the stimulation ability (Fig. 4, B). Summary potentiation of fragments DD and $E_{1} E_{2}$ is close to the effect of initial fragment of DDE-complex.

Effect of FDPs on polymeric fibrin lysis by plasminogen. Turbidimetric analysis of desAB fibrin clot destruction by t-PA-activated plasminogen have shown a decrease of the reaction rate caused by intermediate degradation products hmFDPs and DDE (70 and $38 \%$ reduction of lysis rate, accordingly). At the same time, fragment DD does not attenuate the fibrin clot lysis by plasmin (Fig. 5).

Effect of FDPs on plasmin inactivation by $\alpha_{2}-$ antiplasmin. None of fibrin fragments, except polymeric fragments hmFDPs, protects plasmin from $\alpha_{2}$-antiplasmin inhibition (Fig. 6). Addition of blood plasma as $\alpha_{2}$-antiplasmin source into the reaction mixture of plasmin and fragment DD or DDE before desAB-fibrin addition leads to clot formation without next hydrolysis. Plasmin inhibition in the presence of fragments DD and DDE has the same pattern as control probe without any effectors. In the presence of hmFDPs, clot hydrolysis by plasmin is also observed, but the plasma amount which totally inhibits plasmin action in control probe results in only $50 \%$ inhibition.

To explain the differences in activity enhancing of various FDPs, some features of structures of this fragments are considered in Fig. 7. Soluble high-molecular weight FDPs contain fibrin protofibrils sections and composed of several $\mathrm{E}$ and $\mathrm{D}$ domains. Potentiation of t-PA-catalyzed plasminogen activation by this primarily degradation product is $86 \%$ of the level on desAB-fibrin. Such effect is caused by the fragment structure that is similar to fibrin.

DDE-complex potentiation effect is close to the plasminogen activation on hmFDPs. We suppose that DDE conserves all plasminogen- and t-PAbinding sites which are exposed in hmFDPs.

It is well established that each D region contains t-PA- and plasminogen-binding sites that include sequences $\gamma 312-324$ and A $\alpha 148-160$, respectively $[1,17]$. In polymeric fibrin these regions are exposed and they mediate ternary complex formation with proenzyme and its activator. D-domain containing fibrin fragments have different ability to interact with immobilized t-PA, anti-A $\alpha 148-160$ mabs and anti- $\gamma 312-324$-mabs: antibodies bound with DDE, but do not bind with fragment DD $[18,2]$. On the other hand in some experiments $[17,19,20]$ DD potentiated plasminogen activation process. Our results confirm potentiation ability of fibrin degradation product DD. Based on this data we assume that plasminogen-activation sites in D-domains remain exposed after destruction of DDE-interaction.

Less potentiation effect of fragment DD in contrast to DDE-complex is probably caused by the absence of E-fragment activation sites. Fragments $\mathrm{E}_{1}$

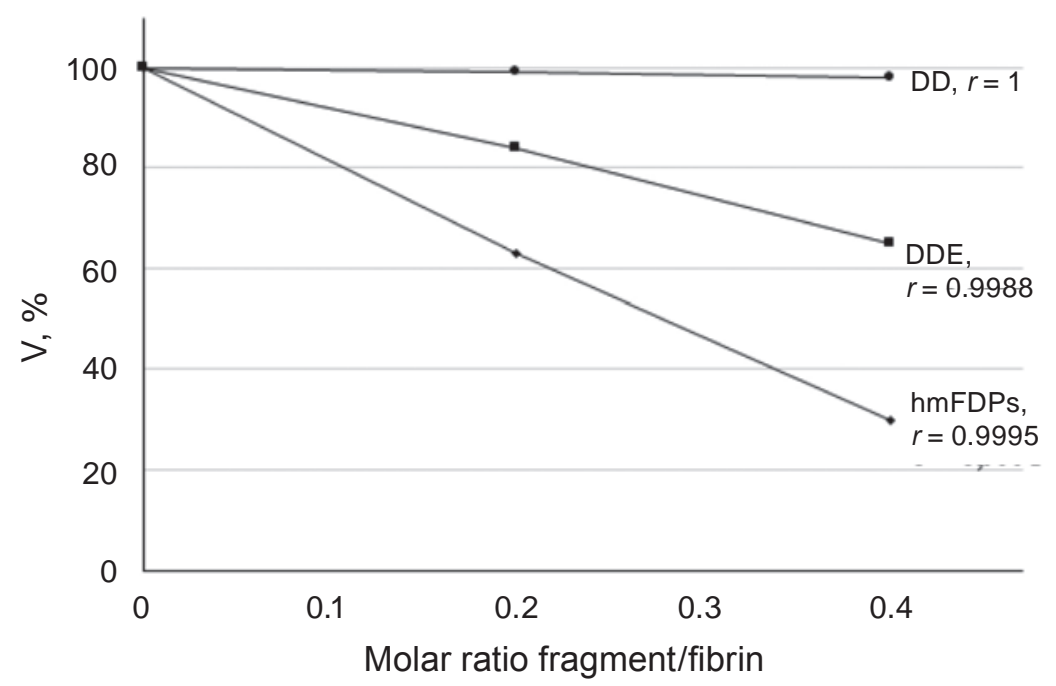

Fig. 5. Effect of FDPs on fibrin clot lysis by tissue-type plasminogen activator-conversed Glu-plasminogen. The lysis rate changes were calculated by comparing the desAB-fibrin clot lysis in the presence of fibrin fragments with that without fragments. These values were than expressed as a percentage of clot lysis rate in the absence of fibrin fragments. The correlation coefficient $r$ was calculated using linear regression analysis 


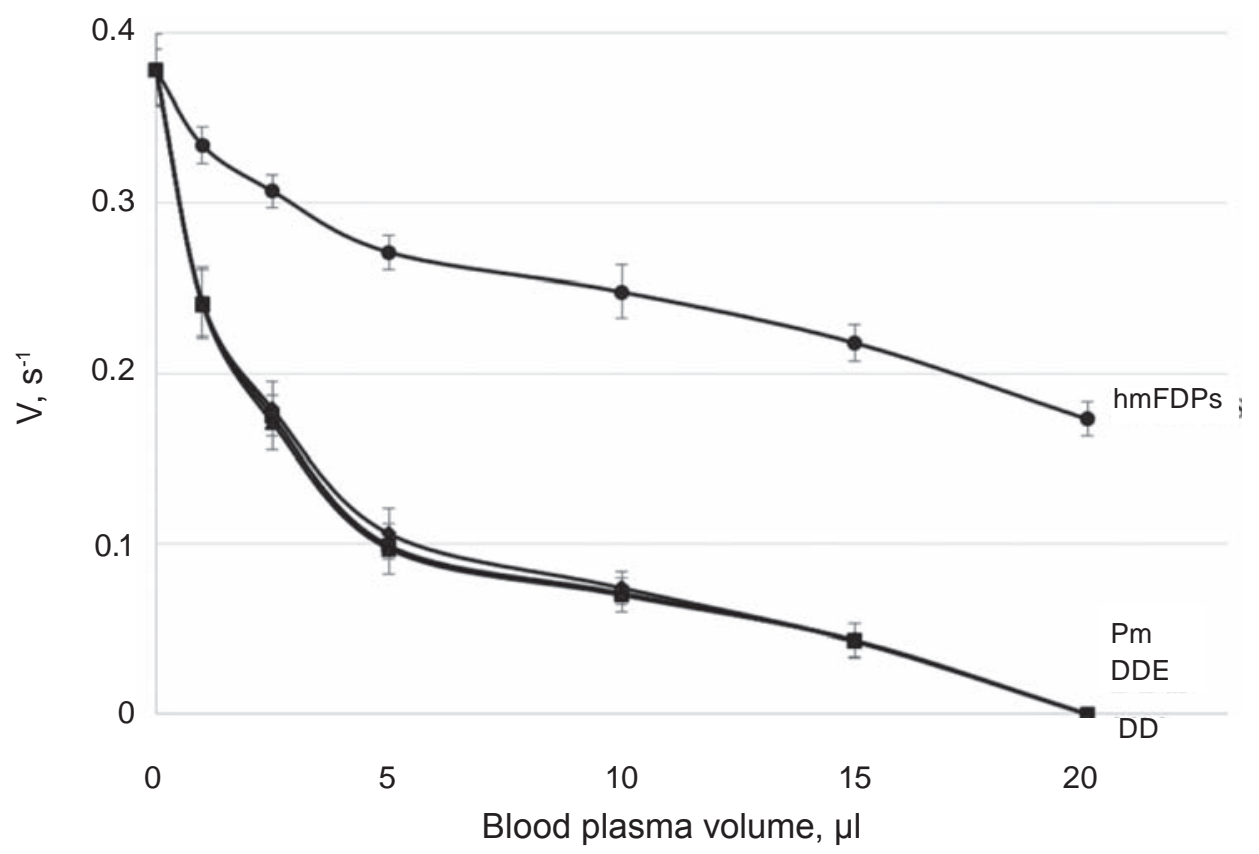

Fig. 6. Plasmin inhibition by a2-antiplasmin in the presence of fibrin fragments. Inhibition is shown as decrease of clot lysis rate. The enzyme was preincubated with fibrin fragments. Plasminogen-depleted blood plasma was added as the inhibitor source before desAB fibrin addition. Plasmin inactivation without FDPs is a control

and $\mathrm{E}_{2}$ are components of DDE-complex and do not exist in bloodstream under fibrinolysis. The fragment is susceptible to further plasmin action as in the following row:

$$
(\mathrm{DD}) \mathrm{E}_{1} \rightarrow(\mathrm{DD}) \mathrm{E}_{2} \rightarrow \mathrm{DD}+\mathrm{E}_{3} \text {. }
$$

The free form of fibrin central domain is the fragment $E_{3}$, which lost amino acid sequences of all three peptide chains (Fig. 7). $\alpha$-Chains of fragment $\mathrm{E}$ are subjected to plasmin splitting off $\alpha$ Gly17-Arg19 peptide. $\beta$-chains lose one of their N-terminal sequences of Gly- $\beta 15$ to Lys- $\beta 53$ during conversion to $\mathrm{E}_{2}$ and the next one during free $\mathrm{E}_{3}$ formation. $\mathrm{C}$ terminal $\beta$ Lys122, $\gamma$ Lys62 are also lost $-\mathrm{E}_{3}$ contains C-terminal $\alpha$ Lys78, $\beta$ Leu120 and $\gamma$ Lys58 [21]. The leakage of potentiation ability on plasminogen activation by t-PA after carboxypeptidase treatment of DDE-compex was found by Stewart and coworkers [22]. In our previous study we have shown that in fibrinogen early fragment $\mathrm{E}$ C-terminal lysine resi-

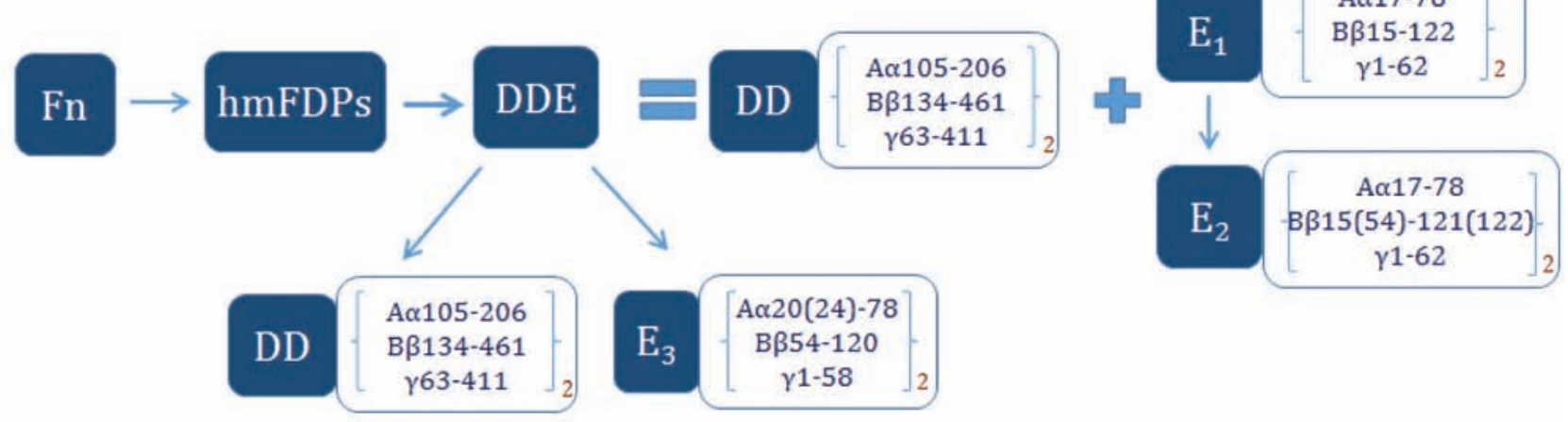

$\rightarrow$ Plasmin action

Fig. 7. Cross-linked fibrin fragmentation by plasmin 
dues of all 3 chain pairs and 16 or 23 amino acid residues of $A \alpha$-chain are essential for plasminogen conversion into plasmin. C-terminal lysines of fragment $\mathrm{E} A \alpha-$ and $\gamma$-chains and lysine-binding site of t-PA kringle 2 are responsible for the interaction between these proteins. Binding of fragment $\mathrm{E}$ to plasminogen is provided by N-terminal A $\alpha 1-19$ and C-terminal B $3120-122$ regions. Late plasmic fibrinogen degradation product fragment EL loses the ability to potentiate plasmin generation but can bind proenzyme and its activator [23]. Thus, the loss of the potentiating action of fibrin fragment $\mathrm{E}_{3}$ probably is associated with the removal of C-terminal lysines and N-terminal fragments from all three polypeptide chains. This data confirms that fragment E, as a component of DDE-comlex, is involved in plasminogen activation.

Intermediate fibrin degradation products like hmFDPs and DDE fragments can compete with fibrin clot for fibrinolytic system components and in this way attenuate the clot lysis that is confirmed by a decrease of polymeric fibrin lysis rate. Despite its ability to stimulate plasminogen activation by t-PA, DD fragment is not an effector for this process. Thus, endpoint fibrin degradation products in clot surroundings can bind plasminogen and t-PA, stimulate proenzyme activation, but do not affect clot destruction.

Ability to protect plasmin from inhibition by plasma $\alpha_{2}$-antiplasmin is inherent only in high molecular weight FDPs, but not in DDE-complex and fragment DD. We suppose it is a regulative mechanism of last fibrinolysis stages: when clot is dissolved to core fragments, plasmin bound to them is inhibited to protect other plasma proteins from nonspecific proteolysis.

Summarizing all the data, a presumable way of FDPs action on fibrinolytic process is in delay of clot lysis rate by the reversed feedback mechanism: more soluble fibrin fragments bind more plasminogen and t-PA and potentiate the activation, move them into bloodstream, where high molecular fibrin fragments are digested to endpoint products and plasmin bound to them are inhibited by the plasma inhibitors.

Fibrin degradation products accumulated in clots microsurrounding can bind plasminogen and its activator and stimulate plasmin formation outward the clot. The intermediate fibrin degradation fragments (hmFDPs) protect plasmin from $\alpha_{2}$ antiplasmin inhibition but under further fragmenta- tion (DDE-complexes, then fragments DD and $\mathrm{E}_{3}$ ) fibrin fragments loose this ability. Fibrinolytic system activity generated by them will be inhibited under the normal level of the plasmin inhibitor. Thereby FDPs can attenuate fibrinolysis by competition for enzymes with clot and FDPs accumulation in clot volume can result in clot resistance to hydrolysis.

\section{ВПЛИВ ПРОДУКТІВ ДЕГРАДАЦІї ФІБРИНУ НА ФІБРИНОЛІТИЧНИЙ ПРОЦЕС}

\section{T. А. Яиенко, В. М. Рибачук, О. І. Юсова, С. М. Харченко, Т. В. Гриненко}

Інститут біохімії ім. О. В. Палладіна НАН України, Київ; e-mail: topolius@yandex.ua

Лізис фібринового згустку плазміноген/ плазміновою системою призводить до утворення низки продуктів деградації фібрину, які вивільнюються в кровотік. Фрагменти фібрину містять у своєму складі специфічні центри зв’язування компонентів фібринолітичної системи і можуть взаємодіяти 3 ними. У роботі досліджено вплив продуктів деградації фібрину на різні етапи фібринолітичного процесу. Показано, що розчинні високомолекулярні продукти деградації фібрину hmFDPs, фрагменти DDEкомплексу та $\mathrm{DD}$, але не кінцевий продукт $\mathrm{E}_{3}$, стимулюють реакцію активації плазміногену тканинним активатором. Одержана за дисоціації DDE-комплексу суміш фрагментів $\mathrm{E}_{1} \mathrm{E}_{2}$ також виявляє стимулювальні властивості. Ранні продукти гідролізу полімерного фібрину hmFDPs та DDE-комплекс пригнічують швидкість лізису фібринового згустку плазміном, а високомолекулярні фрагменти hmFDPs захищають плазмін від інгібування $\alpha_{2}$-антиплазміном. Інгібітори плазми крові пригнічують активність плазміну, зв'язаного з DDE-комплексом i DD фрагментом. Одержані результати свідчать, що фібринові фрагменти, що утворюються під час тромболізису, можуть зв'язувати і виводити 3 об'єму згустку компоненти фібринолітичної системи і в такий спосіб спричиняти його стійкість до гідролізу.

К л ю ч о в і с ло в а: продукти деградації фібрину, плазміноген, t-PА, активація, стимулювальний ефект, інгібування плазміну. 


\section{ВЛИЯНИЕ ПРОДУКТОВ ДЕГРАДАЦИИ ФИБРИНА НА ФИБРИНОЛИТИЧЕСКИЙ ПРОЦЕСС}

\author{
Т. А. Яиенко, В. Н. Рыбачук, Е. И. Юсова, \\ С. М. Харченко, Т. В. Гриненко
}

\author{
Институт биохимии им. А. В. Палладина \\ НАН Украины, Киев; \\ e-mail: topolius@yandex.ua
}

Лизис фибринового сгустка плазминоген/ плазминовой системой приводит к образованию ряда продуктов деградации фибрина, которые освобождаются в кровоток. Фрагменты фибрина содержат в своем составе специфические центры связывания компонентов фибринолитической системы и могут взаимодействовать с ними. В данной работе исследовано влияние продуктов деградации фибрина на различные этапы фибринолитического процесса. Показано, что растворимые высокомолекулярные продукты деградации фибрина hmFDPs, фрагменты DDE-комплекса и DD, но не конечный продукт $\mathrm{E}_{3}$, стимулируют активацию плазминогена тканевым активатором. Полученная при диссоциации DDE-комплекса смесь фрагментов $\mathrm{E}_{1} \mathrm{E}_{2}$ также проявляет стимулирующие свойства. Ранние продукты гидролиза полимерного фибрина hmFDPs и DDE-комплекс снижают скорость лизиса фибринового сгустка плазмином, а высокомолекулярные фрагменты hmFDPs защищают плазмин от действия $\alpha_{2}$-антиплазмина. Ингибиторы плазмы крови подавляют активность плазмина, связанного с DDE-комплексом и $\mathrm{DD}$-фрагментом. Полученные результаты свидетельствуют, что фрагменты фибрина, образованные во время лизиса тромба, могут связывать и выводить из объема сгустка компоненты фибринолитической системы, приводя, таким образом, к его устойчивости к гидролизу.

Кл ю че вы е слов а: продукты деградации фибрина, плазминоген, t-PA, активация, стимулирующий эффект, ингибирование плазмина.

\section{References}

1. Aisina RB, Mukhametova LI. Structure and functions of plasminogen/plasmin system. Bioorg Khim. 2014; 40(6): 642-657. (In Russian).

2. Yakovlev S, Makogonenko E, Kurochkina N, Nieuwenhuizen $\mathrm{W}$, Ingham $\mathrm{K}$, Medved $\mathrm{L}$.
Conversion of fibrinogen to fibrin: mechanism of exposure of tPA- and plasminogen-binding sites. Biochemistry. 2000; 39(51): 15730-15741.

3. Lugovskoy EV, Makogonenko EM, Komisarenko SV. Molecular mechanisms of formation and degradation of fibrin. Physical, chemical and immunochemical analysis. K.: Naukova Dumka, 2013. 230 p. (In Russian).

4. Schuliga M. The inflammatory actions of coagulant and fibrinolytic proteases in disease. Mediators Inflamm. 2015; 2015: 437695.

5. Weitz JI, Leslie B, Ginsberg J. Soluble fibrin degradation products potentiate tissue plasminogen activator-induced fibrinogen proteolysis. J Clin Invest. 1991; 87(3): 1082-1090.

6. Stewart RJ, Fredenburgh JC, Weitz JI. Characterization of the interactions of plasminogen and tissue and vampire bat plasminogen activators with fibrinogen, fibrin, and the complex of D-dimer noncovalently linked to fragment E. J Biol Chem. 1998; 273(29): 18292-18299.

7. Robson SC, Shephard EG, Kirsch RE. Fibrin degradation product D-dimer induces the synthesis and release of biologically active IL-1 beta, IL-6 and plasminogen activator inhibitors from monocytes in vitro. Br J Haematol. 1994; 86(2): 322-326.

8. Naito M, Stirk CM, Smith EB, Thompson WD. Smooth muscle cell outgrowth stimulated by fibrin degradation products. The potential role of fibrin fragment $E$ in restenosis and atherogenesis. Thromb Res. 2000; 98(2): 165-174.

9. Jennewein C, Tran N, Paulus P, Ellinghaus P, Eble JA, Zacharowski K. Novel aspects of fibrin(ogen) fragments during inflammation. Mol Med. 2011; 17(5-6): 568-573.

10. Varetska TV. Microgeterogenety of fibrinogen. Cryofibrinogen. Ukr Biokhim Zhurn. 1960; 32(1): 13-24. (In Russian).

11. Deutsch DG, Mertz ET. Plasminogen: purification from human plasma by affinity chromatography. Science. 1970; 170(3962): 1095-1096.

12. Pozdnjakova TM, Musjalkovskaja AA, Ugarova TP, Protvin DD, Kotsjuruba VN. On the properties of fibrin monomer prepared from fibrin clot with acetic acid. Thromb Res. 1979; 16(1-2): 283-288.

13. Belitser VA, Platonova TN, Musialkovskaia AA. Inhibition of fibrin monomer polymerization by fibrinolysis products - fragments D and DD. 
Dokl Akad Nauk SSSR. 1986; 291(4): 1001-1004. (In Russian).

14. Olexa SA, Budzynski AZ. Primary soluble plasmic degradation product of human crosslinked fibrin. Isolation and stoichiometry of the (DD)E complex. Biochemistry. 1979; 18(6): 991995.

15. Ugarova TP, Budzynski AZ. Interaction between complementary polymerization sites in the structural D and E domains of human fibrin. J Biol Chem. 1992; 267(19): 13687-13693.

16. Bouvier SA, Beretta-Piccoli M, Giacometti N. Light scattering measurements of polimerization and depolimerization of fibrin: a tool for studing coagulation and fibrinolysis. Progress in chemical fibrinolysis and thrombolysis. Eds. Davidson JF. et al. N.Y.: Raven Press. 1975; 1: 281-288.

17. Nieuwenhuizen W. Fibrin-mediated plasminogen activation. Ann N Y Acad Sci. 2001; 936: 237246.

18. Medved L, Tsurupa G, Yakovlev S. Conformational changes upon conversion of fibrinogen into fibrin. The mechanisms of exposure of cryptic sites. Ann N Y Acad Sci. 2001; 936: 185 204.

19. Hasan AA, Chang WS, Budzynski AZ. Binding of fibrin fragments to one-chain and two-chain tissue-type plasminogen activator. Blood. 1992; 79(9): 2313-2321.
20. Skomorovskaya EV, Grinenko TV, Platonova TN. Interaction between Glu-plasminogen and Lysplasminogen with DH-dimer / Abstract book of the XVth Congress of International Society on thrombosis and haemostasis. Jerusalem, Israel. 1995.

21. Olexa SA, Budzynski AZ, Doolittle RF, Cottrell BA, Greene TC. Structure of fragment $\mathrm{E}$ species from human cross-linked fibrin. Biochemistry. 1981; 20(21): 6139-6145.

22. Stewart RJ, Fredenburgh JC, Rischke JA, Bajzar L, Weitz JI. Thrombin-activable fibrinolysis inhibitor attenuates (DD)E-mediated stimulation of plasminogen activation by reducing the affinity of (DD)E for tissue plasminogen activator. A potential mechanism for enhancing the fibrin specificity of tissue plasminogen activator. J Biol Chem. 2000; 275(47):36612-36620.

23. Yatsenko T, Rybachuk VN, Kharchenko SM, Grinenko TV, Yusova EI. Effect of fribrinigen degradation products on various stages of the fibrinolytic process. J Pre-Clin Clin Res. 2015; 9(1): 18-22.

Received 28.01.2016 